\title{
STOK KARBON PADA HUTAN RAWA BERDASARKAN FUNGSI KAWASAN HUTAN DI PROVINSI PAPUA BARAT
}

\section{Carbon Stock in Swamp Forests Based on Forest Function Area in West Papua Province}

\author{
Destri $^{1}$, Keliopas Krey ${ }^{1}$, Zulfikar Mardiyadi ${ }^{*}$

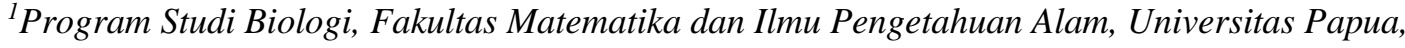 \\ Manokwari 98314, Indonesia \\ ${ }^{2}$ Program Studi Kehutanan, Fakultas Kehutanan, Universitas Papua, Manokwari 98314, Indonesia
}

*Korespondensi: z.mardiyadi@gmail.com

\begin{abstract}
Considering the importance of forests for human life, both in the local, national and global context (climate change), Indonesia seeks to find ways to make forests continue to play a role as economic resources, contribute to improving the lives of surrounding communities, maintain sustainability and contribute to reducing emissions greenhouse gas. The alternative is to maintain and utilize the ability of forests to absorb and store carbon, including Swamp Forests, Swamp Forests are forests that grow and develop in areas or areas that are always flooded with fresh water and carbon stocks are carbon stocks found in nature. The purpose of this study was to calculate the swamp forest area in West Papua Province, calculate the amount of carbon stock in swamp forests in West Papua Province, analyze the potential emissions caused by exploitation of swamp forests, calculate the economic value of $\mathrm{CO}_{2}$ uptake in swamp forests.
\end{abstract}

\begin{abstract}
ABSTRAK
Mengingat begitu pentingnya hutan bagi kehidupan manusia, baik dalam lingkup lokal, nasional maupun konteks global (perubahan iklim) Indonesia berupaya menemukan cara bagaimana menjadikan hutan itu tetap berperan sebagai sumber perekonomian, menyumbang pada perbaikan hidup masyarakat sekitar hutan, terjaga kelestariannya dan berkontribusi pada penurunan emisi gas rumah kaca. Alternatifnya adalah dengan menjaga serta memanfaatkan kemampuan hutan dalam menyerap dan menyimpan karbon termasuk Hutan Rawa, Hutan Rawa adalah hutan yang tumbuh dan berkembang pada kawasan atau wilayah yang selalu tergenang air tawar dan Stok karbon adalah cadangan karbon yang terdapat di alam. Tujuan dilakukannya penelitian ini adalah untuk Menghitung luasan Hutan Rawa di Provinsi Papua Barat, Menghitung jumlah stok karbon Hutan Rawa di Provinsi Papua Barat, Menganalisa berapa potensi emisi yang diakibatkan jika terjadi eksploitasi pada Hutan Rawa, Menghitung berapa nilai ekonomi serapan $\mathrm{CO}_{2}$ pada Hutan Rawa.
\end{abstract}

Keywords: Carbon Stock, Swamp, Climate, Western Papua

\section{PENDAHULUAN}

Global warming dan perubahan iklim telah menjadi isu sekaligus fenomena alam yang dibicarakan oleh seluruh dunia. Disaat bersamaan isu ini telah menunjukkan dampaknya yang dirasakan di berbagai belahan bumi termasuk wilayah Indonesia. Kegiatan konversi lahan (land use, land use change and forestry/LULUCF) menyumbang emisi Gas Rumah Kaca (GRK) sebesar 33\% di seluruh dunia dan Indonesia termasuk salah satu penyumbang emisi GRK terbesar (Houghton et al.,2000). Pada tahun 2000 total emisi berkisar antara emisi 1.378 juta ton $\mathrm{CO}_{2}$-eq dan sekitar 821 juta ton $\mathrm{CO}_{2}$-eq(60\%) dari emisi tersebut berasal dari sektor LULUCF (MoE 2010). Emisi dari kegiatan LULUCF tersebut secara global dalam periode 20 tahun terakhir mencapai 1,65 GtC/tahun dan lebih dari $80 \%$ berasal dari negara berkembang terlebih khusus negara yang yang berhutan tropis (Houghton et al.,2000).

Kegiatan manusia telah meningkatkan konsentrasi GRK yang sebelumnya secara alami 
telah ada. Peningkatan penggunaan energi dari bahan bakar minyak untuk berbagai kegiatan manusia terutama dalam proses industri, transportasi, dan kegiatan pembukaan hutan untuk keperluan pembangunan, intensifikasi budidaya tanaman serta produksi limbah, telah menyebabkan emisi gas-gas rumah kaca meningkat dengan laju yang semakin cepat.

Enam jenis GRK yang keberadaanya di atmosfer berpotensi menyebabkan perubahan iklim global dan dibicarakan di UNFCC adalah: Karbon $\left(\mathrm{CO}_{2}\right)$, Metana $\left(\mathrm{CH}_{4}\right)$, Nitrat Oksida $\left(\mathrm{N}_{2} \mathrm{O}\right)$, dan gas yang mengandung fluor seperti Hydrofluoracarbon (HFCs), Perfluoracarbon (PFCs), Sulphur hexafluorida( SF6), (Martono, 2012). Dari keenam gas rumah kaca tersebut, karbondioksida mengambil peran paling besar yakni $75 \%$, oleh karena itulah maka jumlah GRK selalu disetarakan dengan kandungan $\mathrm{CO}_{2}$ yang berada di atmosfer.

Hutan merupakan sumber daya alam hayati yang dapat menjadi sumber emisi karbon dan juga dapat menjadi penyerap karbon dan menyimpannya. Potensi penurunan emisi tentunya dapat meningkatkan kapasitas hutan dalam menyerap dan menyimpan karbon. Penyerapan karbon terjadi didasarkan atas proses kimiawi dalam aktivitas proses fotosintesis pada tumbuhan yang menyerap $\mathrm{CO}_{2}$ dari atmosfer dan air dari tanah yang kemudian di proses dan menghasilkan oksigen dan karbohidrat yang selanjutnya akan berakumulasi menjadi selulosa dan lignin sebagai cadangan karbon (Murdiyarso et al. 2007).

Upaya mitigasi terhadap perubahan iklim diwujudkan dengan kesepakatan global bertajuk United Nations Framework on Climate change (UNFCC) yang melibatkan negara-negara di dunia. Indonesia telah menyampaikan target penurunan emisi pada tahun 2030 sebesar $29 \%$ dengan upaya sendiri dan $41 \%$ dengan bantuan internasional (KLHK 2016).

Provinsi Papua Barat dengan luas sekitar 9.730.550 Ha terdapat luas hutan 8,810.248 Ha $(89.88 \%)$ dan non hutan seluas 991.890 (10.20\%), sedangkan hutan rawa seluas 746.924 ha $(7.62 \%)$. Hutan rawa yang ada terdiri dari hutan rawa primer seluas 7.45 ha dan hutan rawa sekunder seluas 1.03 ha.
Peranan penting hutan rawa bagi mahluk hidup dan juga mengurangi emisi gas rumah kaca, maka penelitian ini diperlukan untuk mendorong terus berkembangnya perhitungan stok karbon pada hutan rawa. Mengetahui potensi kandungan karbon yang tersimpan dalam hutan rawa di Papua Barat tentunya akan mendukung pembangunan berkelanjutan global.

\section{METODE}

Penelitian ini menggunakan metode deskriptif dengan teknik analisis interpretasi dan analisis peta. Interpretasi peta dilakukan terhadap data perubahan tutupan lahan 27 tahun terakhir. Data dikumpulkan dari peta tutupan lahan Kementrian Lingkungan Hidup dan Kehutanan tahun 1990, 1996, 2000, 2003, 2006, 2009, 2011, 2012, 2013, 2014, 2015, 2016 dan 2017 (KLHK), peta batas administrasi kabupaten, dan peta fungsi hutan. Selain luas hutan rawa Papua Barat $(\mathrm{Ha})$, stok karbon $(\mathrm{C})$, potensi emisi $\left(\mathrm{CO}_{2)}\right.$, dan nilai ekonomi serapan $\mathrm{CO}_{2}(\mathrm{Rp})$. Peta batas administrasi kabupaten dan peta fungsi hutan.

\section{Processing}

Kodefikasi

Tahap ini merupakan tahap perubahan kode yang dilakukan setiap kelas tipe tutupan lahan Papua Barat berdasarkan kodefikasi yang ditetapkan oleh Kementerian Lingkungan Hidup dan Kehutanan sesuai Peraturan Direktur Jenderal Nomor P.1/VII-IPSDH/2015 (Tabel 1). Kodefikasi dilakukan pada setiap peta tutupan lahan Papua Barat selama 27 tahun terakhir. Proses kodefikasi dilakukan dengan bantuan software Archmap 10.4.

\section{Overlay}

Setelah proses kodefikasi dilanjutkan dengan overlay peta. Overlay merupakan proses penyatuan data (tumpang tindih) layer yang berbeda untuk menghasilkan peta yang baru yang utuh. Proses overlay dilakukan pada peta tutupan lahan Papua Barat tahun 1990, 1996, 2000, 2003, 2006, 2009, 2011, 2012, 2013,2014, 2015, 2016, 2017 dengan peta batas administrasi kabupaten dan dan peta fungsi hutan.

Data tutupan lahan Papua Barat dianalisis pada Microsoft Excel menggunakan Pivot Table 
untuk mengetahui perubahan lahan khusunya pada hutan rawa primer dan hutan rawa sekunder selama 27 tahun terakhir. Pivot merupakan salah satu fitur pada program excel untuk merangkum, menganalisa, dan mengeksplorasi serta mempresentasikan data.

Tabel 1. Kodefikasi

\begin{tabular}{lcl}
\hline \multicolumn{1}{c}{ Kelas } & Kode & \multicolumn{1}{c}{ Keterangan } \\
\hline Hutan Rawa Primer & Hrp/2005 & $\begin{array}{l}\text { Seluruh kenampakan hutan di daerah berawa, } \\
\text { termasuk rawa payau dan rawa gambut yang belum } \\
\text { menampakkan bekas penebangan, termasuk hutan } \\
\text { sagu }\end{array}$ \\
\hline Hutan Rawa Sekunder/ & Hrs/20051 & $\begin{array}{l}\text { Seluruh kenampakan hutan di daerah berawa, } \\
\text { termasuk rawa payau dan rawa gambut yang telah } \\
\text { bekas tebangan }\end{array}$ \\
& $\begin{array}{l}\text { menampakkan bekas penebangan. Termasuk hutan } \\
\text { sagu dan hutan bekas terbakar, bekas tebangan parah } \\
\text { jika tidak menampakkan genangan (liputan air) } \\
\text { digolongkan tanah terbuka. Sedangkan jika bekas } \\
\text { genangan digolongkan tubuh air (rawa). }\end{array}$ \\
\hline
\end{tabular}

Perhitungan jumlah stok karbon dilakukan dengan menggunakan formula:

\section{Jumlah Stok Karbon= Faktor Emisi $x$ Luas}

Nilai stok karbon yang ditetapkan oleh Kementerian Lingkungan Hidup dan Kehutanan tahun 2016 dapat dilihat pada Tabel 2.

Tabel 2. Nilai Stok Karbon

\begin{tabular}{lc}
\hline \multirow{2}{*}{ Tipe Penutupan Lahan } & Stock (Ton C) \\
\cline { 2 - 2 } & KLHK \\
\hline Hutan Rawa Sekunder & 68,479 \\
Hutan Rawa Primer & 84,036 \\
\hline
\end{tabular}

Tabel 3. Nilai Ekonomi Stok Karbon

\begin{tabular}{ccc}
\hline \multicolumn{3}{c}{ Nilai Ekonomi } \\
Carbonfix & $\begin{array}{c}\text { Sistem dan } \\
\text { Standar } \\
\text { Plan Vivo }\end{array}$ & $\begin{array}{c}\text { Voluntary } \\
\text { Carbon Standar } \\
\text { (AFOLU) }\end{array}$ \\
\hline 10-20 Euro & 8-30 US\$ & $12-18$ US\$ \\
(14-27 US\$) & & \\
\hline
\end{tabular}

Perhitungan potensi emisi di lakukan dengan menggunakan formula:

\section{Potensi Emisi= Jumlah Stok C x 3,667}

Nilai Ekonomi dihitung berdasarkan Permenhut P.36 tahun 2009 yang disajikan pada Tabel 3. Perhitungan Nilai Ekonomi dilakukan dengan menggunakan formula:

Nilai ekonomi/Ha= Ton C x 3,667 x Harga Total Ekonomi= Nilai Ekonomi/Ha $\times$ Luas

\section{HASIL DAN PEMBAHASAN}

\section{Luas Hutan Rawa di Provinsi Papua Barat}

Analisis peta tutupan lahan Kementerian Lingkungan Hidup dan Kehutanan tahun 19902017 menunjukkan bahwa total luas hutan rawa di Provinsi Papua Barat pada tahun 1990 seluas 748.317 Ha terdiri dari hutan rawa primer (HRP) seluas 688.054 ha dan hutan rawa sekunder (HRS) seluas 60.263 ha. Sedangkan pada tahun 2017 seluas 743.567 ha yang terdiri dari hutan rawa primer seluas 653.335 ha $(87.86 \%)$ dan hutan rawa sekunder 90.232 ha (12.14\%).

Wilayah Papua Barat masih didominasi oleh Hutan Rawa Primer (Gambar 1). Namun luas Hutan Rawa Primer terus mengalami penurunan dan Hutan Rawa Sekunder mengalami peningkatan dari tahun ke tahun dengan laju perubahan hutan baik yang direncanakan maupun yang tidak direncanakan.

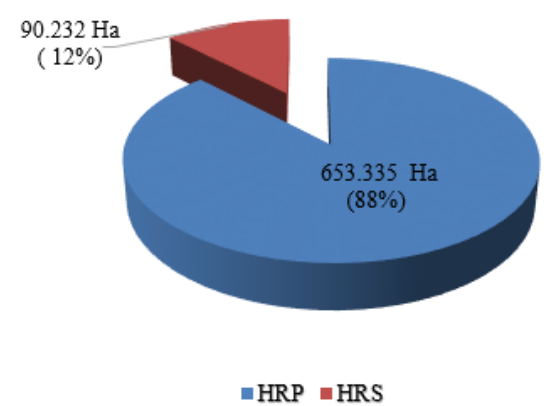

Gambar 1. Diagram luas hutan rawa primer dan hutan rawa sekunder Provinsi Papua Barat tahun 2017 
Selama kurung waktu 27 tahun (1990 hingga 2017) terjadi perubahan pada luas Hutan Rawa yakni Hutan Rawa Primer mengalami penurunan meski tidak signifikan sedangkan pada Hutan Rawa Sekunder mengalami peningkatan (Gambar 2). Hal ini dapat terjadi karena kegiatan penebangan hutan yang terus dilakukan yang menyebabkan menurunnya kualitas tegakan hutan.

Analisis perubahan tutupan lahan (Gambar 3) yang dilakukan pada tahun 1990-2017 menunjukkan bahwa selama periode tersebut terjadi penurunan pada Hutan Rawa Primer seluas 34.719 (54\%) dan terjadi peningkatan pada Hutan Rawa Sekunder seluas 29.969 Ha (46\%). Perubahan yang terjadi pada Hutan Rawa selama periode tersebut disebabkan karena adanya kegiatan yang berkaitan dengan izin usaha pemanfaatan hutan secara langsung maupun tidak langsung yang dapat menyebabkan terjadinya penurunan kualitas hutan dan perubahan tutupan lahan untuk berbagai kepentingan daerah seperti pertanian, perkebunan atau sarana prasarana umum di daerah tersebut.

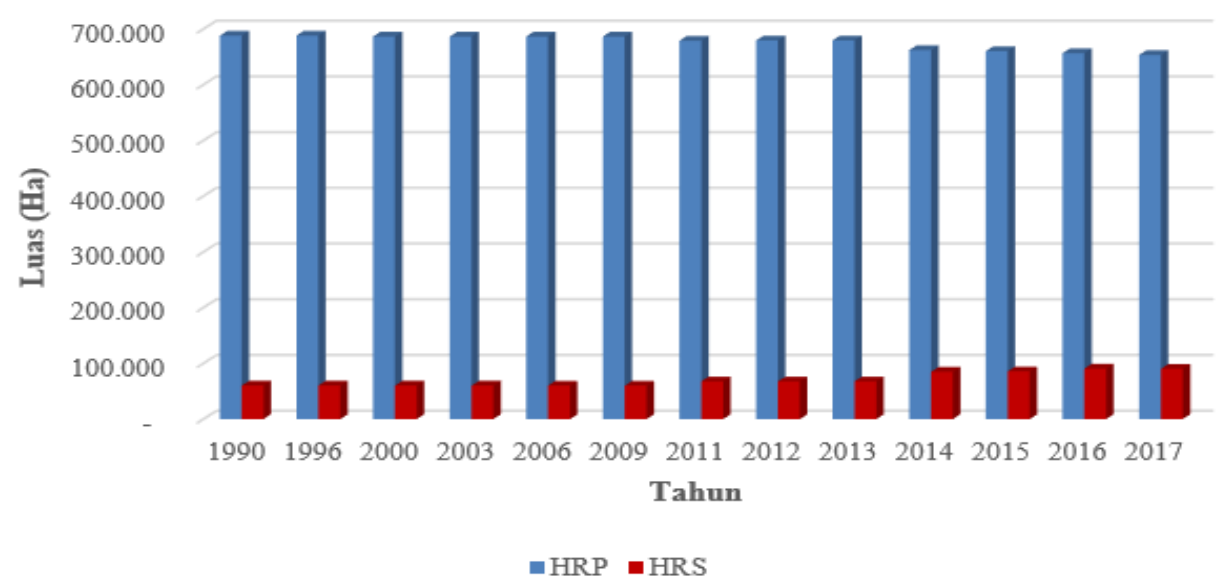

Gambar 2. Perubahan luas Hutan Rawa Primer dan Hutan Rawa Sekunder di Provinsi Papua Barat pada Tahun 1990-2017

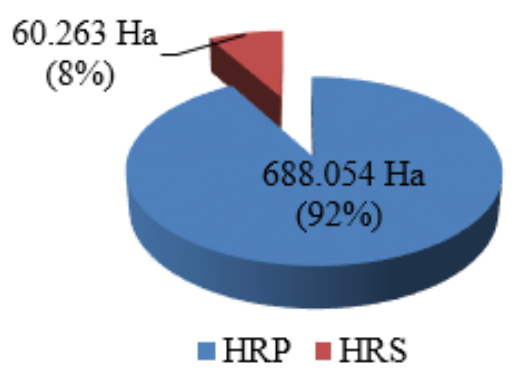

(A)

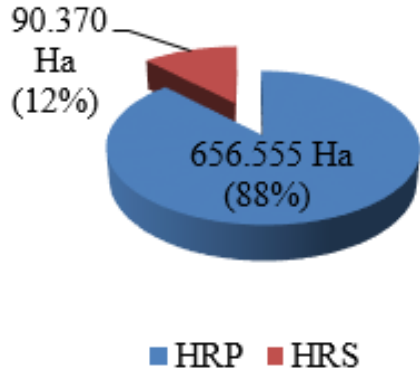

(B)

Gambar 3. Diagram presentase luas Hutan Rawa pada tahun 1990 (A) dan tahun 2017 (B)

Luas Hutan Rawa berdasarkan Kabupaten di Provinsi Papua Barat

Sebelas kabupaten di Papua Barat diidentifikasi memiliki hutan rawa (Gambar 4). Seluruhnya ke 11 kabupaten tersebut terletak pada wilayah dengan garis pantai yang luas. Berdasarkan hasil analisis peta tutupan lahan KLHK tahun 2017 menunjukkan bahwa total luas hutan rawa tertinggi di Kabupaten Bintuni seluas 360.308 ha. Dimana hutan rawa primer seluas $316.623 \mathrm{Ha}(88 \%)$ dan hutan rawa sekunder seluas 43.686 ha (12\%). Sedangkan hutan rawa terendah terdapat di Kabupaten Manokwari dengan luas total seluas 1.304 ha terdiri dari hutan rawa primer seluas 835 ha (64\%) dan hutan rawa sekunder seluas 468 ha (36\%). 


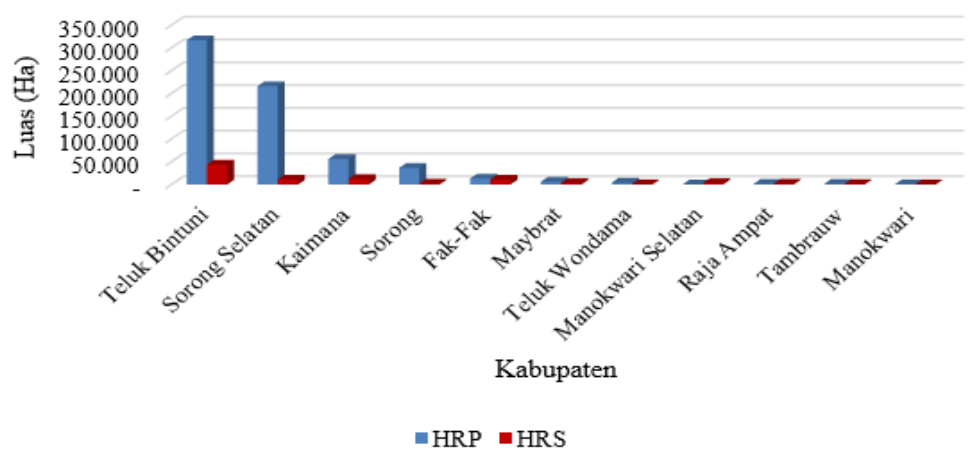

Gambar 4. Luas Hutan Rawa Primer dan Hutan Rawa Sekunder berdasarkan Kabupaten di Provinsi Papua Barat tahun 2017

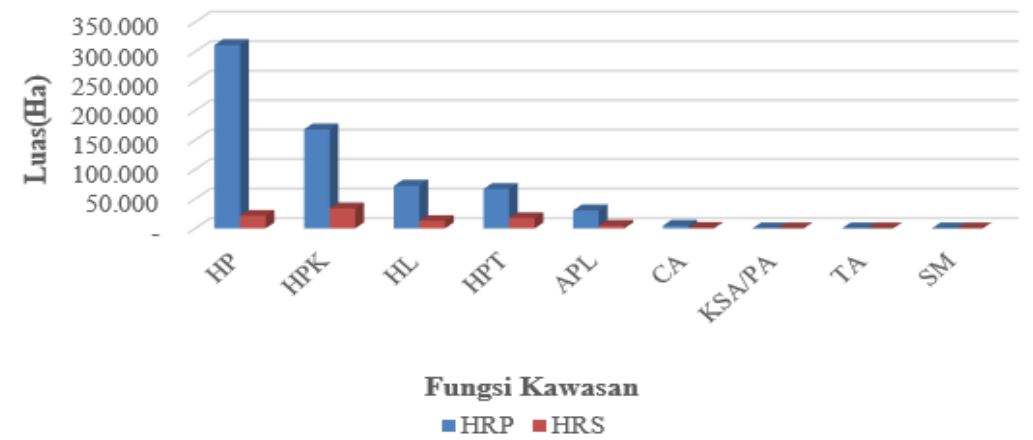

Gambar 5. Presentase luas Hutan Rawa Primer dan Hutan Rawa Sekunder berdasarkan fungsi kawasan Hutan tahun 2017

Kabupaten Teluk Bintuni merupakan dataran rendah luas yang dialiri banyak sungai dan didominasi oleh berbagai macam rawa yang tergenang. Sungai-sungai mengendapkan aluvium di sepanjang pinggirannya membentuk tanggul yang bertambah tinggi dan membentuk rawa-rawa. Proses alami ini sangat menunjang perkembangan ekosistem mangrove. Ekosistem mangrove terbesar di Indonesia berada di Teluk Bintuni (Kartikasari et al. 2012). Seluruhnya sungai-sungai dan rawa-rawa terapit oleh tepian pantai yang disanggah oleh ekosistem mangrove sebagai buffer zone.

Kabupaten Manokwari merupakan kota yang memiliki Hutan Rawa terendah di Provinsi Papua Barat hal ini dikarenakan Kabupaten Manokwari telah mengalami perubahan tutupan lahan selama 27 tahun belakangan ini yaitu selama periode tahun 1990-2013 dimana Hutan Rawa Primer berubah menjadi Hutan Rawa Sekunder. Perubahan tersebut mengakibatkan Kabupaten Manokwari memiliki luas Hutan Rawa terendah dibandingkan dengan Kabupaten yang lain yang ada di Provinsi Papua Barat.

\section{Luas Hutan Rawa berdasarkan Fungsi Kawasan Hutan di Provinsi Papua Barat}

Selama tahun 1990-2017 total luas hutan rawa adalah 9.706.346 ha namun selama periode itu terjadi penurunan luas hutan rawa primer 34.719 ha (54\%) dan terjadi peningkatan hutan rawa sekunder 29.969 ha (46\%). Total luas hutan rawa tertinggi pada 2017 terdapat di hutan produksi (HP) seluas 332.280 ha terdiri dari hutan rawa primer seluas 311.090 ha (48\%) dan hutan rawa sekunder seluas 21.190 ha (23\%) (Gambar 5). Disusul dengan hutan produksi konversi (HPK) dengan seluas 201.875 ha yang terdiri dari hutan rawa primer seluas 167.874 ha (26\%) dan hutan rawa sekunder seluas 34.002 ha $(38 \%)$.

Luas hutan rawa terendah berada pada tubuh air termasuk kawasan suaka alam/ perlindungan alam. Hasil analisis ini ternyata $100 \%$ dari total 37 ha luasan hutan rawa tubuh air merupakan hutan rawa primer. Sedangkan kawasan suaka alam dengan total 95 ha luasan hutan rawa 87 ha $(0.01 \%)$ hutan rawa primer dan sisanya 8 ha $(0.01 \%)$ hutan rawa sekunder. 
Stok Karbon Hutan Rawa di Provinsi Papua Barat

Stok Karbon merupakan cadangan karbon yang terdapat di alam atau banyaknya kandungan karbon yang ada di pohon pada suatu areal hutan. Melalui fotosintesis $\mathrm{CO}_{2}$ diserap dan diubah oleh tumbuhan menjadi karbon organik dalam bentuk biomassa. Kandungan absolut dalam biomassa pada waktu tertentu dikenal dengan istilah stok karbon (carbon stock) (Apss et al. 2003). Hutan memainkan peranan yang penting sebagai sumber emisi dan serapan gar rumah kaca, penurunan emisi sektor kehutanan dapat dilakukan dengan menjaga dan mempertahankan stok karbon dan meningkatkan serapan melalui penanaman.

Mengetahui potensi karbon hutan diperlukan pengetahuan dan pemahaman oleh berbagai pihak termasuk masyarakat luas untuk mengukur dan menghitung cadangan karbon hutan, prinsipnya adalah melalui kombinasi kegiatan pengukuran lapangan dan hasil citra satelit (remote sensing) (Wibowo et al., 2013).

Perhitungan stok karbon dilakukan menggunakan perkalian antara luas tutupan hutan rawa dengan nilai faktor emisi berdasarkan tipe tutupan lahan yang telah ditetapkan secara resmi oleh KLHK tahun 2016 dan Badan Perencanaan Pembangunan Nasional (BAPPENAS) tahun 2010. Faktor emisi KLHK digunakan saat akan menghitung emisi dalam skala dunia (internasional) sedangkan faktor emisi BAPPENAS digunakan untuk skala nasional. Berikut adalah hasil analisis Stok Karbon tutupan lahan Hutan Rawa Primer dan Hutan Rawa Sekunder di Provinsi Papua Barat.

Total stok karbon hutan rawa Papua Barat pada tahun 2017 berdasarkan faktor emisi KLHK sebesar 61.082.691 ton $\mathrm{C}$ yang terdiri dari hutan rawa primer sebesar 54.903.679 ton C (90\%) dan hutan rawa sekunder sebesar 6.179.011ton $\mathrm{C}$ (10\%) (Gambar 6). Sedangkan berdasarkan faktor emisi BAPPENAS menunjukkan bahwa total stok karbon di Papua Barat tahun 2017 sebesar 142.039.697 ton $\mathrm{C}$ terdiri dari hutan rawa primer 128.053.705 ton C (90\%) dan hutan rawa sekunder sebesar 13.985.992 ton C (10\%).

\section{Stok Karbon Hutan Rawa berdasarkan Fungsi Kawasan Hutan}

Stok Karbon pada hutan rawa primer berdasarkan fungsi kawasan hutan (Gambar 7) menurut faktor emisi KLHK tertinggi terdapat di hutan produksi (HP) sebesar 26.142.742 ton c (56\%), disusul dengan hutan lindung sebesar 6.079 .883 ton c $(13 \%)$ dan terendah terdapat di suaka margasatwa sebesar 0 ton c (0\%). Sedangkan hutan rawa sekunder tertinggi terdapat di hutan produksi (HP) sebesar 1.451 .039 ton c (29\%), disusul hutan produksi konversi (HPK) dan hutan produksi terbatas (HPT) sebesar 1.186 .360 ton c (24\%) dan terendah di suaka margasatwa (SM) sebesar 0 ton c $(0 \%)$.

Berdasarkan BAPPENAS hutan rawa primer tertinggi pada hutan produksi sebesar 60.973 .599 ton c (67\%). Selanjutnya adalah HPK sebesar 32.903 .234 ton c (36\%) dan terendah terdapat di SM sebesar 0 ton c (0\%) sedangkan hutan rawa sekunder tertinggi terdapat pada HPK sebesar 5.270.276 ton c (38\%) disusul HP sebesar 3.284 .501 ton c (23\%) dan terendah terdapat di SM sebesar 0 ton c $(0 \%)$.

\section{Potensi Emisi $\left(\mathrm{CO}_{2}\right)$ Hutan Rawa di Provinsi Papua Barat}

Penurunan kualitas penutupan lahan dari primer menjadi sekunder maupun kehilangan identitas sebagai hutan mengakibatkan terlepasnya emisi ke atmosfer. Emisi $\mathrm{CO}_{2}$ dapat dihitung dengan melakukan perkalian antara data aktivitas dengan faktor emisi. Data aktivitas yang digunakan adalah data faktor emisi tutupan hutan pulau Papua yang bersumber dari KLHK dan BAPPENAS. Hasil perhitungan emisi karbondioksida $\left(\mathrm{CO}_{2}\right)$ di Provinsi Papua Barat dapat dilihat pada Tabel 4.

Total emisi $\mathrm{CO}_{2}$ yang dihasilkan oleh hutan rawa pada tahun 1990 berdasarkan faktor emisi KLHK pada hutan rawa primer sebesar 212.030.748 ton $\mathrm{CO}_{2}$ dan hutan rawa sekunder sebesar 15.132.808 ton $\mathrm{CO}_{2}$. Pada tahun 2017 berdarkan faktor emisi KLHK pada hutan rawa primer sebesar 201.331.792 ton $\mathrm{CO}_{2}$ dan hutan rawa sekunder 22.658.435 ton $\mathrm{CO}_{2}$. Sedangkan 
jika dilihat berdasarkan faktor emisi BAPPENAS tahun 1990 pada hutan rawa primer sebesar 494.526.472 ton $\mathrm{CO}_{2}$ dan hutan rawa sekunder sebesar 34.252.622 ton $\mathrm{CO}_{2}$. Tahun 2017 hutan rawa primer sebesar 469.572.935 ton $\mathrm{CO}_{2}$ dan hutan rawa sekunder sebesar 51.286.634 ton $\mathrm{CO}_{2}$.

\section{Potensi Emisi $\mathrm{CO}_{2}$ berdasarkan Fungsi Kawasan Hutan}

Hasil perhitungan emisi karbondioksida $\left(\mathrm{CO}_{2}\right)$ di Provinsi Papua Barat berdasarkan fungsi kawasan hutan (Tabel 5) menunjukkan bahwa total emisi $\mathrm{CO}_{2}$ yang dihasilkan oleh hutan rawa pada tahun 1990 berdasarkan faktor emisi KLHK

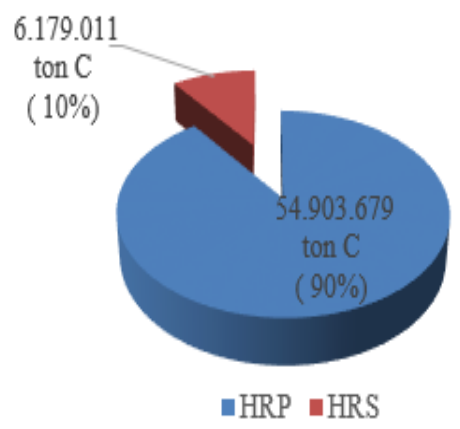

(A) pada hutan rawa primer sebesar 212.030.709 ton $\mathrm{CO}_{2}$ dan hutan rawa sekunder sebesar 15.132.808 ton $\mathrm{CO}_{2}$. Sedangkan pada tahun 2017 berdasarkan faktor emisi KLHK pada hutan rawa primer sebesar 201.331.792 ton $\mathrm{CO}_{2}$ dan hutan rawa sekunder sebesar 22.658.435 ton $\mathrm{CO}_{2}$. Namun jika berdasarkan faktor emisi BAPPENAS pada tahun 1990 hutan rawa primer sebesar 494.526.381 ton $\mathrm{CO}_{2}$ dan hutan rawa sekunder sebesar 34.252.662 ton $\mathrm{CO}_{2}$. Pada tahun 2017 berdasarkan faktor emisi BAPPENAS hutan rawa primer sebesar 469.572.936 ton $\mathrm{CO}_{2}$ dan hutan rawa sekunder sebesar 51.286.634 ton $\mathrm{CO}_{2}$.

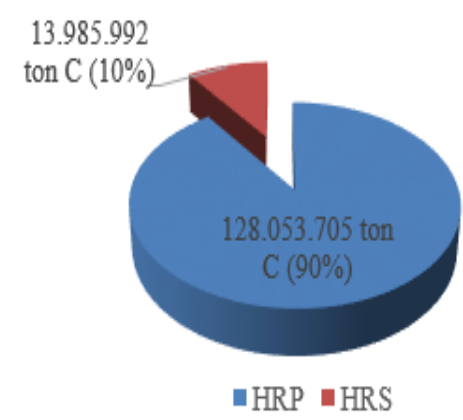

(B)

Gambar 6. Diagram Stok Karbon Hutan Rawa tahun 2017 berdasarkan faktor emisi KLHK (A) dan faktor emisi BAPPENAS (B)

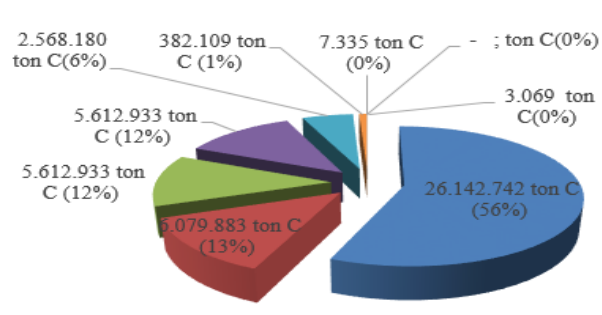

(A)

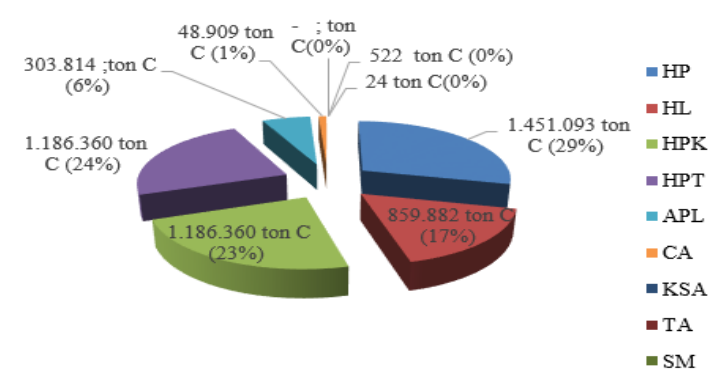

(B)
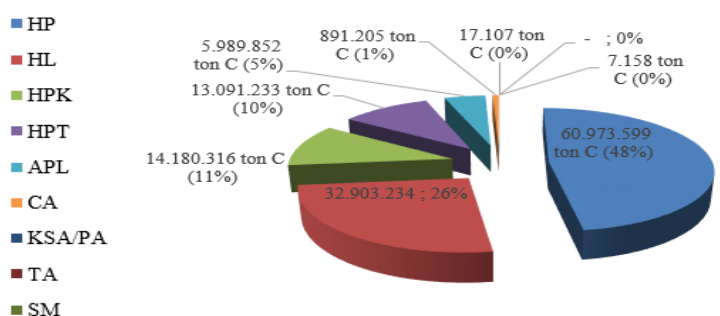

(C)

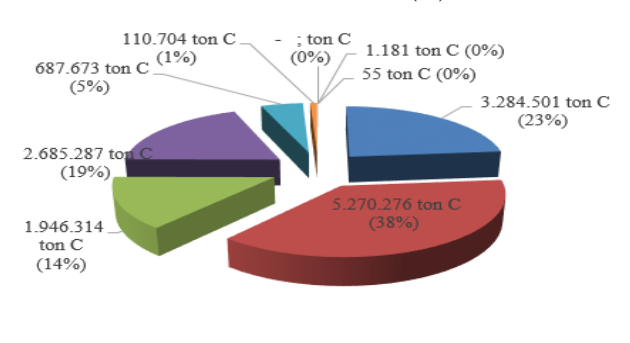

(D)
$=\mathrm{HP}$

= HPK

$=\mathrm{HL}$

- HPT

-APL

$\because \mathrm{CA}$

- KSA/PA

- TA

- SM

- HP

= HPK

$=\mathrm{HI}$

=HPT

$=$ APL

$=\mathrm{CA}$

-KSA/PA

-TA

- SM

Gambar 7. Stok Karbon Hutan Rawa Berdasarkan Fungsi Kawasan Hutan menurut faktor emisi KLHK dan BAPPENAS. Hutan Rawa Primer (A), (C); Hutan Rawa Sekunder (B), (D) 
Tabel 4. Data Potensi Emisi Hutan Rawa di Provinsi Papua Barat Periode tahun 1990-2017 berdasarkan KLHK dan BAPPENAS

\begin{tabular}{cccccc}
\hline \multirow{2}{*}{ No } & \multirow{2}{*}{ Tahun } & \multicolumn{2}{c}{ Emisi KLHK $\left(\mathrm{TonCO}_{2}\right)$} & \multicolumn{2}{c}{$\begin{array}{c}\text { Emisi BAPPENAS } \\
\left(\mathrm{TonCO}_{2}\right)\end{array}$} \\
\cline { 3 - 6 } & & HRP & HRS & HRP & HRS \\
\hline 1 & 1990 & 212.030 .709 & 15.132 .808 & 494.526 .381 & 34.252 .622 \\
2 & 1996 & 212.030 .709 & 15.132 .808 & 494.526 .381 & 34.252 .622 \\
3 & 2000 & 211.548 .814 & 15.091 .772 & 493.402 .440 & 34.159 .737 \\
4 & 2003 & 211.548 .814 & 15.091 .772 & 493.402 .440 & 34.259 .737 \\
5 & 2006 & 211.548 .814 & 15.060 .740 & 493.402 .440 & 34.089 .497 \\
6 & 2009 & 211.548 .814 & 15.053 .310 & 493.402 .440 & 34.072 .679 \\
7 & 2011 & 209.207 .015 & 16.961 .588 & 487.940 .584 & 38.392 .005 \\
8 & 2012 & 209.385 .914 & 16.979 .675 & 488.357 .837 & 38.432 .946 \\
9 & 2013 & 205.769 .276 & 19.913 .763 & 479.922 .630 & 45.074 .159 \\
10 & 2014 & 204.039 .045 & 21.304 .011 & 475.887 .153 & 48.220 .940 \\
11 & 2015 & 203.445 .093 & 21.450 .609 & 474.501 .858 & 48.552 .760 \\
12 & 2016 & 202.323 .899 & 22.692 .906 & 471.886 .860 & 51.364 .659 \\
13 & 2017 & 201.331 .792 & 22.658 .435 & 469.572 .936 & 51.286 .634 \\
\hline
\end{tabular}

Tabel 5. Data Potensi Emisi Hutan Rawa berdasarkan Fungsi Kawasan Hutan di Provinsi Papua Barat pada periode tahun 1990-2017 berdasarkan KLHK dan BAPPENAS

\begin{tabular}{cccccc}
\hline \multirow{2}{*}{ No } & \multirow{2}{*}{ Tahun } & \multicolumn{2}{c}{ Emisi KLHK $\left(\mathrm{TonCO}_{2}\right)$} & \multicolumn{2}{c}{$\begin{array}{c}\text { Emisi BAPPENAS } \\
\left(\mathrm{TonCO}_{2}\right)\end{array}$} \\
\cline { 3 - 6 } & & HRP & HRS & HRP & HRS \\
\hline 1 & 1990 & 212.030 .709 & 15.132 .808 & 494.526 .381 & 34.252 .622 \\
2 & 1996 & 212.030 .709 & 15.132 .808 & 494.526 .381 & 34.252 .622 \\
3 & 2000 & 211.548 .814 & 15.091 .772 & 493.402 .440 & 34.159 .737 \\
4 & 2003 & 211.548 .814 & 15.091 .772 & 493.402 .440 & 34.259 .737 \\
5 & 2006 & 211.548 .814 & 15.060 .740 & 493.402 .440 & 34.089 .497 \\
6 & 2009 & 211.548 .814 & 15.053 .310 & 493.402 .440 & 34.072 .679 \\
7 & 2011 & 209.207 .015 & 16.961 .588 & 487.940 .584 & 38.392 .005 \\
8 & 2012 & 209.385 .914 & 16.979 .675 & 488.357 .837 & 38.432 .946 \\
9 & 2013 & 205.769 .276 & 19.913 .763 & 479.922 .630 & 45.074 .159 \\
10 & 2014 & 204.039 .045 & 21.304 .011 & 475.887 .153 & 48.220 .940 \\
11 & 2015 & 203.445 .093 & 21.450 .609 & 474.501 .858 & 48.552 .760 \\
12 & 2016 & 202.323 .899 & 22.692 .906 & 471.886 .860 & 51.364 .659 \\
13 & 2017 & 201.331 .792 & 22.658 .435 & 469.572 .936 & 51.286 .634 \\
\hline
\end{tabular}

Nilai Ekonomi Hutan Rawa di Provinsi Papua Barat

Perdangangan karbon hutan adalah pertukaran uang oleh pembeli kepada penyedia atas upaya penyerapan dan penyimpanan karbon dalam biomassa hutan. Dalam pelaksanaan perdagangan karbon antar negara sebagai bentuk kerjasama negara-negara di dunia dalam menyelamatkan bumi dari Pemanasan global membutuhkan perjanjian (persetujuan) yang nantinya akan mengikat para pihak dalam melakukan proses perdagangan karbon. ERPA (Emission Reduction Purchase Agreement) merupakan perjanjian perdagangan karbon dalam rangka pelaksanaan program CDM (Clean Development Mechanism) yang bertujuan untuk mengurangi emisi karbon sebagai salah satu cara untuk menagani masalah pemanasan global.

Total nilai karbondioksida diperoleh dari perhitungan serapan $\mathrm{CO}_{2}$ (ton/Ha) yang dikalikan dengan nilai dolar minimum dan maximum dimana 1 US\$ = Rp. 13.500-,. Total nilai ekonomi karbon yang dihasilkan dari potensi emisi hutan rawa Papua Barat untuk hutan rawa primer dan sekunder berdasarkan KLHK dan BAPPENAS dapat dilihat pada Tabel 6 dan 7 . 
Tabel 6. Data Nilai Ekonomi Hutan Rawa Primer dan Hutan Rawa Sekunder di Provinsi Papua Barat berdasarkan faktor emisi KLHK

\begin{tabular}{|c|c|c|c|c|c|c|c|c|}
\hline \multirow{3}{*}{ No. } & \multirow{3}{*}{ Tahun } & \multirow{3}{*}{$\underset{\text { (ton) }}{\text { Emisi CO2 }}$} & \multicolumn{6}{|c|}{ Nilai Ekonomi $(\operatorname{Rp} \times \mathbf{X} 1.000)$} \\
\hline & & & \multicolumn{2}{|c|}{ Standard Carbonfix } & \multicolumn{2}{|c|}{ Plan Vivo } & \multicolumn{2}{|c|}{ Voulantary Carbon Standard } \\
\hline & & & Minimum (USS 14) & Maximum (USS 27) & Minimum (USS 8) & Maximum (USS 30) & Minimum ( USS 12) & Maximum (USS 18) \\
\hline 1 & 1090 & 212.030 .748 & 40.073 .811 .341 & & & 85.872 .452 .873 & 34.348 .081 .149 & 51.523 .471 .724 \\
\hline 2 & 1996 & 212.030 .748 & 40.073.811.341 & 77.285 .207 .586 & 22.899 .320 .766 & 85.872 .452 .873 & 34.348.981.149 & 51.523 .471 .724 \\
\hline 3 & 2000 & 211.548 .852 & 30.982 .733 .118 & 77.109 .556 .728 & 22.847 .276 .068 & 85.677 .285 .253 & 34.270.914.101 & 51.406 .371 .152 \\
\hline 4 & 2003 & 211.548 .852 & 39.982 .733 .118 & 77.109 .556 .728 & 22.847 .276 .068 & 85.677 .285 .253 & 34.270-914.101 & 51.406 .371 .152 \\
\hline $\begin{array}{l}5 \\
6\end{array}$ & $\begin{array}{l}2006 \\
2009\end{array}$ & $\begin{array}{l}211.548 .852 \\
211.54852\end{array}$ & $\begin{array}{l}39.982 .733 .118 \\
39.982 .733 .118\end{array}$ & $\begin{array}{l}77.109 .556 .728 \\
77.109556 .728\end{array}$ & $\begin{aligned} 22.847 .776 .068 \\
22.847 .276 .068\end{aligned}$ & $\begin{array}{l}85.677 .285 .253 \\
85.677 .285 .253\end{array}$ & $\begin{array}{l}34.270 .914 .101 \\
34.270 .914 .101\end{array}$ & $\begin{array}{l}51.406 .371 .152 \\
51.406\end{array}$ \\
\hline 7 & 2011 & 209.207 .054 & 39.540 .133 .140 & 76.255 .971 .057 & 22.594 .361 .795 & 84.728 .856 .730 & $\begin{array}{l}33.891 .542 .692 \\
33\end{array}$ & $\begin{array}{l}51.406 .371 .152 \\
50837314.038\end{array}$ \\
\hline 8 & & 209.385 .953 & 39.573 .945 .142 & 76.321.179.916 & 22.613 .682 .938 & 84.801 .311 .018 & 33920524,407 & 50.880786611 \\
\hline & & 209.385 .953 & 39.573 .945 .142 & 76.321 .179 .916 & 22.613 .682 .938 & 84.801 .311 .018 & 33.920 .524 .407 & 5088076611 \\
\hline 10 & 2014 & 204.039 .053 & 38563380989 & 74.372234764 & 22036217708 & 8263516405 & 33054326562 & 49581489843 \\
\hline 11 & 2015 & 203.445 .100 & 38.451 .123 .994 & 74.155 .739 .132 & 21.972 .070 .854 & 82.395 .265 .702 & 32.958 .106 .281 & 49.437.159.421 \\
\hline 12 & 2016 & 202.323 .907 & 38.239 .218 .366 & 73.747.063.991 & 21.850 .981 .923 & 81.941 .182 .212 & 32.776 .472 .885 & $\begin{array}{l}49.164 .709 .327 \\
\end{array}$ \\
\hline 13 & 2017 & 201.331 .792 & 38.051 .708 .646 & 73.385.438.104 & 21.743 .833 .512 & 81.539 .375 .671 & 32.615 .750 .268 & 48.923.625.403 \\
\hline \multirow{3}{*}{ No. } & \multirow{3}{*}{ Tahun } & \multirow{3}{*}{$\underset{\text { (ton) }}{\text { Emisi }}$} & \multirow{2}{*}{\multicolumn{4}{|c|}{$\begin{array}{c}\text { Nilai Ekonomi (Rp X 1.000) } \\
\text { Plan Vivo } \\
\end{array}$}} & \multirow{2}{*}{\multicolumn{2}{|c|}{ Voulantary Carbon Standard }} \\
\hline & & & & & & & & \\
\hline & & & Minimum ( USS 14) & Maximum (USS 27) & Minimum ( USS 8) & Maximum (USS 30) & Minimum ( USS 12) & Maximum (USS 18) \\
\hline 1 & 1990 & 15.132 .808 & 2.860 .100 .762 & 5.515 .908 .613 & 1.634 .343 .293 & 6.128 .787 .348 & 2.451 .514 .939 & 3.677 .272 .409 \\
\hline & 1996 & 15.132 .808 & 2.860 .100 .762 & 5.515 .908 .613 & 1.634 .343 .293 & 0.128 .787 .348 & 2.451 .514 .939 & 3.677 .272 .409 \\
\hline 3 & 2000 & & 2.852 .344 .877 & & 1.629 .911 .358 & 6.112 .167 .594 & 2.444 .867 .038 & 3.667 .300 .557 \\
\hline & 2003 & & 2.852 .344 .877 & & & 6.112 .167 .594 & 2.444 .867 .038 & 3.667 .300 .557 \\
\hline 5 & 2006 & $\begin{array}{l}15.060 .740 \\
15.503 .310\end{array}$ & $\begin{array}{l}2.846 .479 .828 \\
2845075-551\end{array}$ & $\begin{array}{r}5.489 .639 .669 \\
5.46931 .420\end{array}$ & 1.626 .559 .902 & 6.099 .599 .632 & 2.439 .839 .853 & 3.659 .759 .779 \\
\hline & $\begin{array}{l}2009 \\
2011\end{array}$ & $\begin{array}{l}15.053 .310 \\
16061588\end{array}$ & $\begin{array}{l}2.845 .075 .551 \\
3.205 .740 .074\end{array}$ & $\begin{array}{l}5.486 .931 .420 \\
6.182 .498 .714\end{array}$ & $\begin{array}{l}1.625 .757 .458 \\
1.831 .851 .471\end{array}$ & $\begin{array}{l}6.096 .590 .466 \\
6869.443016\end{array}$ & $\begin{array}{l}2.438 .636 .186 \\
2747.777 .206\end{array}$ & $\begin{array}{l}3.657 .954 .280 \\
4121.665 .810\end{array}$ \\
\hline 8 & 2012 & 16.979 .675 & $\begin{array}{l}3.203 .740 .074 \\
3.200 .158 .655\end{array}$ & $\begin{array}{l}6.182 .498 .714 \\
6.180 .091 .691\end{array}$ & $\begin{array}{l}1.831 .851 .411 \\
1.833 .804 .946\end{array}$ & $\begin{array}{l}6.8699 .4433 .016 \\
6.876 .768 .546\end{array}$ & $\begin{array}{l}2.7777 .7777 .206 \\
2.750 .707 .418\end{array}$ & $\begin{array}{l}4.121 .665 .810 \\
4.126 .061 .127\end{array}$ \\
\hline 9 & 2013 & 16.979 .6 & 3.209 .158 .655 & 6.189 .091 .691 & 1.833 .804 .946 & 6.876 .768 .546 & 2.750 .707 .418 & 4.126 .061 .127 \\
\hline & & & & & & & & \\
\hline 11 & 2015 & 21.450 & 4.054.169.896 & 7.818.756.227 & 2.316 .668 .512 & $8.687 .506 \mathrm{C}>\mathrm{C}$ & 3.475.002.768 & 5.212 .504 .151 \\
\hline 12 & & 226929 & & 8271568537 & 2450835122 & 9190.631708 & 3676252683 & \\
\hline 13 & 2017 & 22.658 .435 & 4.282.444.227 & 8.258 .999 .581 & 2.447 .110 .987 & 9.176 .666 .201 & 3.670 .666 .481 & 5.505 .999 .721 \\
\hline
\end{tabular}

Tabel 7. Data Nilai Ekonomi Hutan Rawa Primer dan Hutan Rawa Sekunder di Provinsi Papua Barat berdasarkan faktor emisi BAPPENAS

\begin{tabular}{|c|c|c|c|c|c|c|c|c|}
\hline \multirow{3}{*}{ No. } & \multirow{3}{*}{ Tahun } & \multirow{3}{*}{$\underset{\text { (ton) }}{\text { Emisi } \mathrm{CO} 2}$} & \multicolumn{6}{|c|}{ Nilai Ekonomi (Rp X 1.000) } \\
\hline & & & \multicolumn{2}{|c|}{ Standard Carbonfix } & \multicolumn{2}{|c|}{$\begin{array}{l}\text { Plan Vivo } \\
\end{array}$} & \multicolumn{2}{|c|}{ Voulantary Carbon Standard } \\
\hline & & & Minimum (USS 14) & Maximum (USS 27) & Minimum ( USS 8 ) & Maximum (USS 30) & Minimum ( USS 12) & Maximum (USS 18) \\
\hline 1 & 1990 & 494.526 .472 & 93.465 .503 .151 & 180.254 .898 .934 & 53.408 .858 .943 & 200.283 .221 .038 & 80.113.288.415 & 120.169 .932 .623 \\
\hline 2 & 1996 & 494.526 .472 & 93.465.503.151 & 180.254 .898 .934 & 53.408 .858 .943 & 200.283 .221 .038 & 80.113 .288 .415 & 120.169 .932 .623 \\
\hline 3 & 2000 & 493.402 .531 & 93.253.078.337 & 179.845 .222 .508 & 53.287 .473 .336 & 199.828 .025 .009 & 79.931.210.004 & 119.896 .815 .005 \\
\hline 4 & 2003 & 493.402 .531 & 93.253.078.337 & 179.845 .222 .508 & 53.287 .473 .336 & 199.828.025.009 & 79.931.210.004 & 119.896 .815 .005 \\
\hline 5 & 2006 & 493.402 .531 & 93.253 .078 .337 & 179.845 .222 .508 & 53.287 .473 .336 & 199.828 .025 .009 & 79.931.210.004 & 119.896 .815 .005 \\
\hline 6 & 2009 & 493.402 .531 & 93.253 .078 .337 & 179.845 .222 .508 & 53.287 .473 .336 & 199.828 .025 .009 & 79.931.210.004 & 119.896 .815 .005 \\
\hline 7 & 2011 & 487.940 .674 & 92.220 .787 .467 & 177.854 .375 .828 & 52.697 .592 .838 & 197.615.973.143 & 79.046.389.257 & 118.569 .583 .886 \\
\hline 8 & 2012 & 488.357 .928 & 92.299 .648 .339 & 178.006 .464 .653 & 52.742 .656 .194 & 197.784 .960 .726 & 79.113.984.290 & 118.670 .976 .435 \\
\hline 9 & 2013 & 8.357 .928 & 92.299 .648 .339 & 178.006 .464 .653 & 52.742 .656 .194 & 197.784 .960 .726 & 79.113 .984 .290 & 118.670 .976 .435 \\
\hline 10 & 2014 & 475.887 .172 & 89.942.675.446 & 173.460 .874 .075 & 51.395 .814 .541 & 192.734 .304 .528 & 77.093 .721 .811 & 115.640 .582 .717 \\
\hline 11 & 2015 & 474.50 & 89.680 .854 .668 & 172.955 .934 .003 & 51.246 .202 .668 & 192.173 .26 & 76.869.304.001 & 115.303 .956 .002 \\
\hline 12 & 2016 & 471.88 & 89.186 .620 .016 & 172.002 .767 .174 & 50.963 .782 .866 & 191.114 .185 .749 & 76.445 .674 .300 & 114.668 .511 .449 \\
\hline 13 & 2017 & 469.572 .935 & 88.749 .284 .767 & 171.159 .334 .908 & 50.713 .877 .010 & 190.177 .038 .787 & 76.070 .815 .515 & 114.106 .223 .272 \\
\hline \multirow{3}{*}{ No. } & \multirow{3}{*}{ Tahun } & \multirow{3}{*}{$\underset{\text { (ton) }}{\text { Emisi CO2 }}$} & \multicolumn{6}{|c|}{ Nilai Ekonomi (Rp X 1.000) } \\
\hline & & & \multicolumn{2}{|c|}{ Standard Carbonfix } & \multicolumn{2}{|c|}{$\begin{array}{l}\text { Plan Vivo } \\
\end{array}$} & \multicolumn{2}{|c|}{ Voulantary Carbon Standard } \\
\hline & & & Minimum ( USS 14) & Maximum (USS 27) & Minimum ( USS 8 ) & ) Maximum (USS 30) & Minimum ( USS 12) & Maximum (USS 18) \\
\hline 1 & 1990 & 34.252 .622 & 6.473 .745 .501 & 12.485 .080 .609 & 3.699 .283 .143 & 13.872 .311 .788 & 5.548 .924 .715 & 8.323 .387 .073 \\
\hline 2 & 1996 & 34.252 .622 & 473.745 .501 & 12.485 .080 .609 & 3.699 .283 .143 & 13.872.311.788 & 5.548 .924 .715 & 8.323.387.073 \\
\hline 3 & 2000 & 34.159 .737 & 456.190 .306 & 12.451 .224 .162 & 3.689 .251 .604 & 13.834 .693 .513 & 5.533 .877 .405 & 8.300 .816 .108 \\
\hline 4 & 2003 & 34.159 .737 & 456.190 .306 & 12.451.224.162 & 3.689 .251 .604 & 13.834.693.513 & 5.533 .877 .405 & 8.300 .816 .108 \\
\hline 5 & 2006 & 089.497 & 442.914 .958 & 12.425 .621 .704 & 3.681 .665 .690 & 13.806 .246 .338 & 5.522 .498 .535 & 8.283 .747 .803 \\
\hline 6 & 2009 & .072 .6 & 6.439 .736 .421 & 12.419 .491 .669 & 3.679 .849 .384 & 13.799 .435 .188 & 5.519 .774 .075 & 8.279 .661 .113 \\
\hline 7 & 2011 & 38.392 .005 & 7.256 .088 .896 & 13.993 .885 .727 & 4.146 .336 .512 & 15.548.761.919 & 6.219 .504 .768 & 9.329 .257 .151 \\
\hline 8 & 2012 & 38.432 .9 & 7.263 .826 .742 & 14.008 .808 .717 & 4.150 .758 .138 & 15.565.343.019 & 6.226 .137 .208 & 9.339 .205 .811 \\
\hline 9 & 2013 & 38.432 .946 & 7.263.826.742 & 14.008 .808 .717 & 4.150 .758 .138 & 15.565 .343 .019 & 6.226 .137 .208 & 9.339 .205 .811 \\
\hline 10 & 2014 & 48.220 .95 & 9.113 .768 .525 & 17.576 .553 .584 & 5.207 .867 .729 & 19.529 .503 .982 & 7.811 .801 .593 & 11.717 .702 .389 \\
\hline 11 & 2015 & 48.552 .817 & 9.176 .482 .335 & 17.697 .501 .646 & 5.243 .704 .191 & 19.663 .890 .718 & 7.865 .556 .287 & 11.798 .334 .431 \\
\hline 12 & 2016 & 51.364 .685 & 9.707 .925 .450 & 18.722 .427 .653 & 5.547 .385 .971 & 20.802 .697 .393 & 8.321 .078 .957 & 12.481 .618 .436 \\
\hline 13 & 2017 & 51.286 .634 & 9.693 .173 .896 & 18.693 .978 .228 & 5.538 .956 .512 & 20.771 .086 .920 & 8.308 .434 .768 & 12.462 .652 .152 \\
\hline
\end{tabular}

SIMPULAN

Total stok karbon hutan rawa Provinsi Papua Barat berdasarkan faktor emisi KLHK selama 27 tahun sebesar 801.463.291 ton C terdiri dari $92 \%$ HRP dan HRS $8 \%$.

Stok karbon tertinggi berdasarkan kabupaten terdapat di Teluk Bintuni sebesar 386.644.643 ton C terdiri dari 92\% HRP dan HRS $8 \%$. Stok karbon tertinggi berdasarkan fungsi kawasan hutan terdapat pada HP sebesar 360.278.316 ton $\mathrm{C}$ terdiri dari $96 \%$ HRP serta HRS $4 \%$.
Berdasarkan faktor emisi BAPPENAS total stok karbon hutan rawa di Provinsi Papua Barat mencapai 1.864.968.198 ton $\mathrm{C}$ terdiri dari HRP sebesar 92\% dan HRS 8\%. Berdasarkan kabupaten stok karbon tertinggi juga terdapat di Teluk Bintuni sebesar 899.581.890 ton C terdiri dari HRP $92 \%$ dan $8 \%$ HRS.

Total potensi emisi di Provinsi Papua Barat selama kurun waktu 27 tahun berdasarkan faktor emisi KLHK sebesar 2.938.965.890 ton $\mathrm{CO}_{2}$ dengan presentasi paling besar pada hutan rawa primer $(92 \%)$. 


\section{UCAPAN TERIMA KASIH}

Banyak pihak telah membantu analisa kami. Set data yang dihimpun merupakan kebaikan dari rekan-rekan di UPT Geospasial UNIPA. Trima kasih kepada Kepala UPT Geospasial UNIPA atas kemudahan akses terhadap data-data yang mahal dan bermutu termasuk telah memfasilitasi penelitian ini sejak perencanaan dan persiapan awal hingga penyelesaian analisa.

\section{DAFTAR PUSTAKA}

Apss, M., M. Artaxo., Barret, J., Canadell, A. 2003. Science statement on current scientific understanding of the processes affecting terrestrial carbon stocks and human influences upon them. IPCCC. Geneva

Houghton, R. A., Butman, D., Bunn, A. G., Krankina, O. N., Schlesinger, P., and Stone, T. A.: Mapping Russian forest biomass with data from satellites and forest inventories, Environ. Res. Lett, 2, 045032, doi:10. 1088/1748-9326/2/4/045032, 2000.

Kementrian Lingkungan Hidup dan Kehutanan (KLHK). 2016. Modul faktor emisi terbaru.
Kartikasari S.N., Marshall A.J, Beehler B.M. 2012. Ekologi Papua. Yayasan Pustaka Obor Indonesia. Jakarta.

Martono. 2012. Buku pedoman penyelenggaraan inventarisasi Gas Rumah Kaca Nasional: Buku 1 pedoman umum.

MoE (Ministry of Environment). 2010. Indonesia Second National Communication Under The United Nations Framework Convention On Climate Change. Jakarta

Murdiyarso, D., U. Rosalina, K. Hairiah, L. Muslihat, INN. Suryadiputra, A. Jaya. 2007. Petunjuk Lapangan : Pendugaan Cadangan Karbon Lahan Gambut. Proyek Climate Change, Forests and Peatlands in Indonesia. Bogor, Indonesia: Wetland International - Indonesia Programme and Wildlife Habitat Canada.

Wibowo Ari., Ismayadi, S., Nurtjahjawilasa, Subarudi, Zahrul Muttaqin. 2013. Petunjuk praktis menghitung cadangan karbon hutan. Pusat Penelitian dan Pengembangan Perubahan Iklim dan Kebijakan Badan Penelitian dan Pengembangan Kehutanan Kementerian Kehutanan, Republik Indonesia Kerjasama dengan United Nations Educational, Scientific and Cultural Organization (UNESCO). 